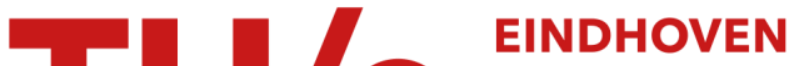 UNIVERSITY OF TECHNOLOGY
}

\section{Strength and microstructure of brazed cemented carbide and silicon nitride joints}

\section{Citation for published version (APA):}

Martens, L., Tillmann, W., Lugscheider, E., \& Ziegler, G. (1996). Strength and microstructure of brazed cemented carbide and silicon nitride joints. Journal of Materials Processing Technology, 58(1), 13-23. https://doi.org/10.1016/0924-0136(95)02103-5

DOI:

10.1016/0924-0136(95)02103-5

Document status and date:

Published: 01/01/1996

\section{Document Version:}

Publisher's PDF, also known as Version of Record (includes final page, issue and volume numbers)

\section{Please check the document version of this publication:}

- A submitted manuscript is the version of the article upon submission and before peer-review. There can be important differences between the submitted version and the official published version of record. People interested in the research are advised to contact the author for the final version of the publication, or visit the $\mathrm{DOI}$ to the publisher's website.

- The final author version and the galley proof are versions of the publication after peer review.

- The final published version features the final layout of the paper including the volume, issue and page numbers.

Link to publication

\section{General rights}

Copyright and moral rights for the publications made accessible in the public portal are retained by the authors and/or other copyright owners and it is a condition of accessing publications that users recognise and abide by the legal requirements associated with these rights.

- Users may download and print one copy of any publication from the public portal for the purpose of private study or research.

- You may not further distribute the material or use it for any profit-making activity or commercial gain

- You may freely distribute the URL identifying the publication in the public portal.

If the publication is distributed under the terms of Article 25fa of the Dutch Copyright Act, indicated by the "Taverne" license above, please follow below link for the End User Agreement:

www.tue.nl/taverne

Take down policy

If you believe that this document breaches copyright please contact us at:

openaccess@tue.nl

providing details and we will investigate your claim. 


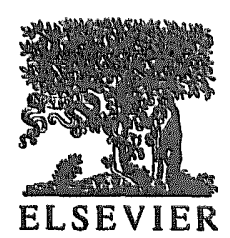

Journal of Manerials Processing Technology 58 (1996) 1323

\title{
Strength and microstructure of brazed cemented carbide and silicon nitride joints
}

\author{
L. Martens ${ }^{\mathrm{a}}$, W. Tillmann ${ }^{\mathrm{b}}$, E. Lugscheider ${ }^{\mathrm{b}}$, G. Ziegler ${ }^{\mathrm{c}}$ \\ "Eindhoven University of Techology, Laboratory of Solid State Chemistry and M.Sc.. PO Box 513. Eindhoten. Netherlands \\ "Aachen University of Technology. Lehr- und Forschangsgebied, Werkstoffirissenschaften, 52056 Aaciten. Germam.

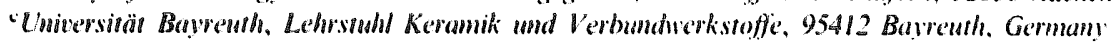

Received 30 March 1994; accepted I July 1994

\begin{abstract}
Industrial summary
Successful application of new high-performance cutting materials can only be achieved if adequate joining techniques are provided. Brazing has been proved to be a promising approach for new advanced materials, such as cemented carbides with low binder concentration, or silicon nitride. In this paper mechanical and microstructural results concerning brazed cemented carbide-steel and silicon nitride-steel joints are presented. AgCuTi active braze has been employed as filler metal owing to the fact that both silicon nitride and cemented carbide cannot be wetted by conventional brazes. In order to reduce thermally induced stresses, various interlayer materials have been examined. Microstructural and mechanical analyses revealed that the joint formation as well as interfacial interactions are of great significance for the joint quality. Although the use of interlayers is supposed to be an effective approach to reduce thermally induced stresses in bi-material joints, the influence of microstructural effects within the joint cannot be neglected. The correlation of experimental results with finite element calculations reveals that there are discrepencies. These can be attributed to the fact that FE analyses do not take into account metallurgical effects.
\end{abstract}

Keywords: Brazing: Cenented carbide joints; Silicon nitride joints

\section{Introduction}

With increasing demands for high performance cutting tools the requirements for the actual cutting bits and the corresponding joining techniques are also rising. New materials, such as cemented carbides reduced in Co binder, and high-performance ceramics like silicon nitride, are available which meet tough requirements. Typical examples for extraordinary applications are the drilling of cast iron, wood or armoured concrete. Although the so-called 'ceramic fever' of the early mid-1980s has suffered many setbacks, owing to drastic cuts in military programmes and to the overestimated material properties of engineering ceramics there is still a growing need for high-performance engineering ceramics. Fig. 1 shows the total advanced ceramic market value for 1992 and the projected growth in the United States [1]. In Fig. 2 the corresponding market values are given for West-Europe [2].

As the figures reveal, there is still a potential growth rate for structural ceramics, particularly for applica- tions in cutting tools. An even larger market is found for cemented carbides. In 1991 the yearly turnover of cemented carbides was 11.5 billion DM with a share of more than $50 \%$ in the field of machining and production technologies. In Fig. 3 the annual consumption of cemented carbides in Germany and Europe is shown [3].$$
{ }_{10} \text { U.S. }
$$

U.S. Market (\$ Billion)

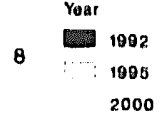

B

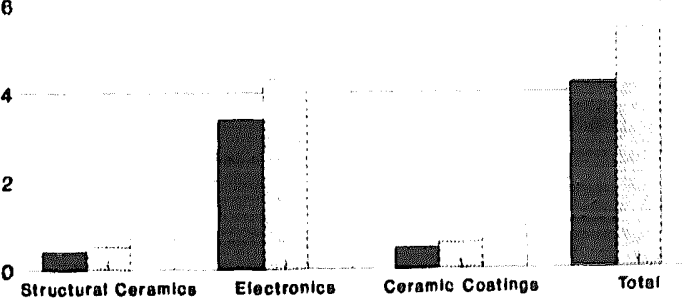

Fig. 1. US markets for advanced ceramics from 1992 to 2000. 


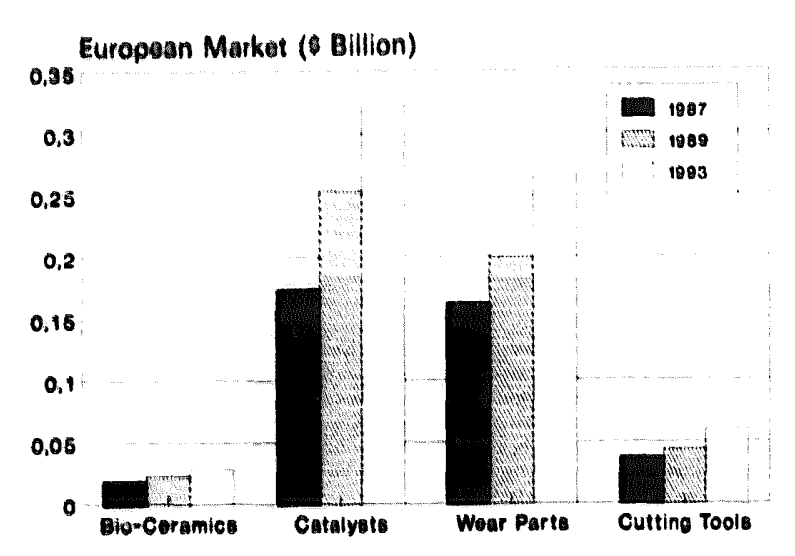

Fig, 2. West-European markets for advanced structural ceramics from 1985 to 1993.

In a lot of cases the application of these high-performance materials relies on adequate joining techniques. Particularly for their use in cutting tools it is crucial to have a joining technique which is adapted to the tough requirements to which the cutting materials are exposed.

Brazing appears to be one of the most flexible joining techniques as it can be adjusted to a broad variety of base materials by changing filler metal's composition. Even ceramics can be wetted and brazed by special brazes without metallization prior to the joining operation. The quality of these joints is exceptionally high and can reach the base material's strength properties provided that the brazing parameters and the filler metals employed are optimized.

The results presented in this paper cover a detailed analysis of the strength and mierostructure of brazed cemented carbide-steel joints und silicon nitride-steel joints. The technologieul background for this combina. tion is the fabrication of cutting tools for the machining of wood or cast steel within the frame of an EEC. funded BRITE/EURAM project. As in many other combinations between high-performance materials, the microstructure of the joint has a strong influence on the mechanical quality and several joint properties can be derived from interfacial interactions.

\section{Fundamentals of brazing silicon nitride and cemented carbide}

In contrast to most steels and several other metals. cemented carbides and silicon nitride are materials which cannot be wetted easily by conventional brazes. This is due to the different atomic structure and therefore bond types of the tungsten carbide in the hard metal and the silicon nitride. Hence, it is crucial to have a reactive braze in order to achieve a metallurgical interaction between braze and base material [4].
Most of the filler metals recommended for the joining of cemented carbides are copper based. Depending on the quality of the cemented carbide, namely the Co content, they contain manganese, nickel, zinc, silicon, titanium, etc. as a reactive agent. Provided that the Co content in the hard metal is fairly high (>10 wt.\%), a decent wetting and bonding reaction can be achieved without the addition of reactive components in the braze alloy [5]. Typical commercially available filler metals for cemented carbides are listed in Table 1. The filler metals are usually employed in furnace brazing (vacuum/shielding gas) without the use of flux.

From a metallurgical point of view the quality of a brazed cemented carbide joint is strongly affected by interfacial interactions. As soon as wetting of the cemented carbide surface is achieved, metallurgical interactions are induced that can lead to various reaction products. The most critical effects are the formation of brittle carbides and micro-voids in the cemented carbide. On the basis of metallurgical analyses a simplified model of the multiphase diffusion can be set up [7]. In Fig. 4 this multi-phase diffusion model for the joining of cemented carbide-steel bonds is shown. Under certain circumstances iron will diffuse out of the steel towards the cemented carbide. Simultaneously carbon and cobalt will diffuse out of the hard metal towards the steel [8]. The carbon diffusion can be regarded as extremely critical on account of the fact that tungsten carbide is liable to change its structure into $(\mathrm{W}, \mathrm{Co})_{6}$ or (W, Co $)_{12} \mathrm{C}$, known as $\eta$-carbides.

The basic requirement for carbon migration is a chemical potential between the cemented carbide and the steel. This can be regarded as a typical constellation found in brazed joints for cutting tools. The steels employed in those joints are usually low-carbon steels in order to provide sufficient ductility. The mechanism of carbon transport depends on the presence of $\mathrm{Fe}-\mathrm{Co}$ precipitates, as carbon is not soluble in copper. Owing to the interfacial interactions mentioned, cobalt as well as iron easily diffuse into the Cu-based filler metal which form $\mathrm{Fe}-\mathrm{Co}$ precipitates in the joint. Depending on the joint clearance, the brazing temperature and the dwell time, these precipitates can grow from the hard metal towards the steel, causing a 'short-cut' for the carbon migration. Furthermore it also possible that carbon interacts with the $\mathrm{Fe}-\mathrm{Co}$ phases under formation of a cementite phase $(\mathrm{Co}, \mathrm{Fe}, \mathrm{W})_{3} \mathrm{C}$ that also embrittles the joint.

Apart from the formation of brittle interfacial reaction products, micropores form in the cemented carbide close to the interface. Owing to the different diffusion rates of iron, carbon and cobalt, the pores are Kirkendall-effect related. The voids can be filled by iron or copper. Provided that the cementite phase (see above) is formed at the interface, this re-diffusion of $\mathrm{Fe}$ or $\mathrm{Cu}$ is restricted [7]. 
Market Hardmetal - Germany in Mio. DM

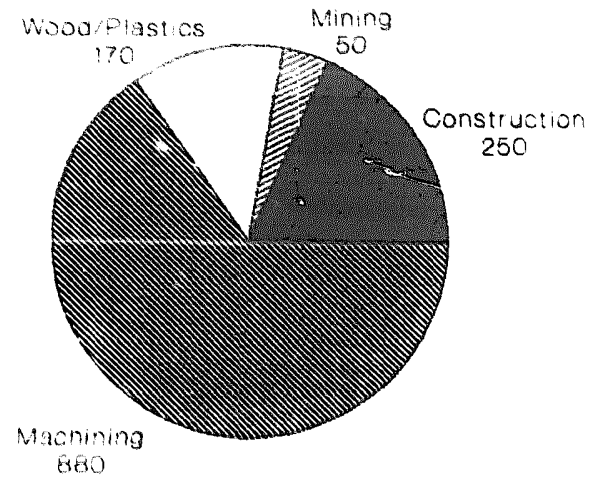

Total: 1350 Mio.DM
Market Hardmetal - West-Europe

in Mio. DM

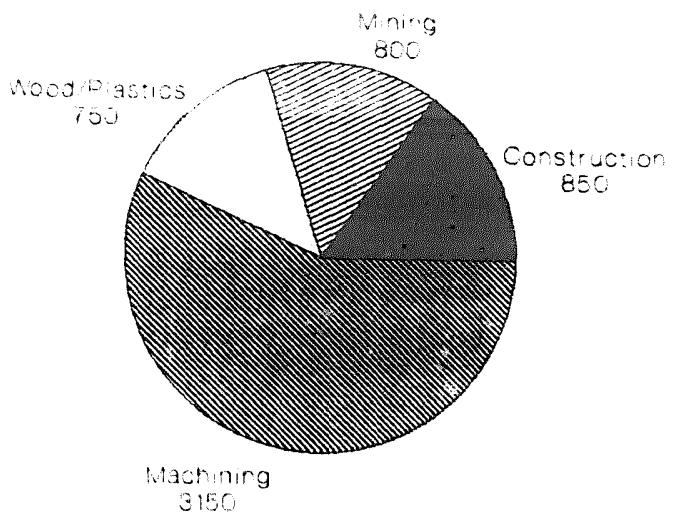

Total: 5550 Mio.DM

Fig. 3. Alulual consumption of cemented carbides in Germany and Europe [3].

The microstructure of brazed silicon nitride joints is dominated by chemical interactions at the interface. A chemical interaction is of great imp. "nnce due to the entirely different atomic structure and 'ond types of bulk ceramics and molten metals. In $r$. .er to induce an interfacial reaction, the filler metal contains a reactive agent which can interact with the ceramic. In commercially available fillers titanium is used as a reactive agent. Being an extremely reactive element, titanium is able to react with the ceramic $\left(\mathrm{Si}_{3} \mathrm{~N}_{4}\right)$ chemically. This chemical reaction leads to the formation of an interfacial reaction layer which is the key to the wetting reaction. In the case of silicon nitride, titanium will form at reaction layer consisting of titanium nitride and titanium silicides [9]. Although the formation of the reaction layer has to be regarded as the basic requirement for wetting, it must not be neglected that it can also have negative effects on the joint quality. From a metallurgical point of view it is important to notice that the reaction layer's composition strongly influences the bonding characteristics. The adhesion between the ceramic-reaction layer and the filler metal is dependent on the atomic and lattice structure of the individual com-

Table 1

Selection of commercially available filler metals for the joining of cemented carbides [6]

\begin{tabular}{llcc}
\hline Filler metals & $\mathrm{T}_{\text {Sol }}\left({ }^{\circ} \mathrm{C}\right)$ & $\mathrm{T}_{\text {Liqu }}\left({ }^{\circ} \mathrm{C}\right)$ & $\mathrm{T}_{\text {Brat }}\left({ }^{\circ} \mathrm{C}\right)$ \\
\hline AgCu16Zn23Mn7.5Ni4.5 & 685 & 705 & 690 \\
AgCu26In6Ni2Mn2 & 730 & 780 & 770 \\
CuZn39.8Si0.2 & 890 & 900 & 900 \\
CuMn12Ni2 & 970 & 990 & 990 \\
CuCo3Mn10 & 980 & 1030 & 1020 \\
\hline
\end{tabular}

pounds. If there is no compatibility between these, the adhesion will be very poor. A typical example for an unfavourable reaction layer formation is the joining of $\mathrm{Si}_{3} \mathrm{~N}_{4}$ with $\mathrm{AgTi}_{4}$. Owing to the high Ti content a thick titanium nitride interfacial reaction layer is formed that causes debonding.

A further aspect in reaction layer formation is the mechanical behaviour of the reaction products. Usually the reaction products are brittle and thus impair the mechanical properties of the joint. From a metallurgical as well as a mechanical point of vicw an active brazed joint should obtain a thin but dense interfacial reaction layer that allows a wetting and bonding reaction and which can atet as at diffusion barrier in order to inhibit

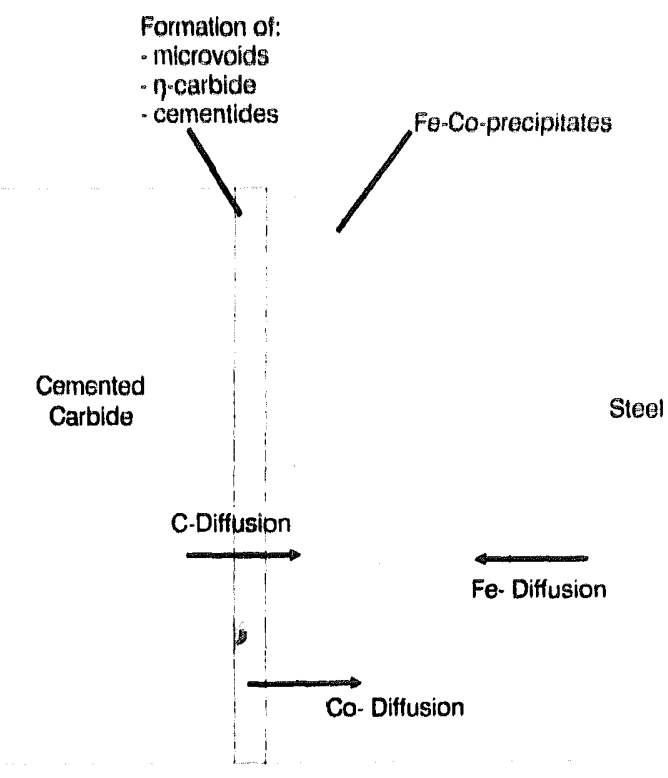

Fig. 4. Multi-phase diffusion in brazed cemented carbide - steel joints. 
too intensive interactions between the reaction agents and the ceramic. These effects can be controlled by the reactive metal concentration and the brazing parameters.

Commercial filler metals always contain titanium as the reactive agent in an $\mathrm{Ag}$-, $\mathrm{AgCu}$ or $\mathrm{AgCuIn}$ matrix. The $\mathrm{Ti}$ concentration varies between 1.5 and $4 \mathrm{wt} . \%$ [11]. In experimental studies it has been proved that a Ti concentration of $1 \mathrm{wt} . \%$ in an AgCuTi system is sufficient for good bonding of $\mathrm{Si}_{3} \mathrm{~N}_{4}$ [11]. The suppliers recommend these active brazes for joining oxide and non-oxide ceramics as well as for the joining of graphite, polycrystalline diamond and cemented carbides. In the siudy described here, a filler metal of the system $\mathrm{AgCu}$ 26.5Ti3 has been used.

\section{Experimental procedure}

The materials employed have been a cemented carbide $(\mathrm{WC} / \mathrm{Co})$ with a reduced Co content and a sintered silicon nitride. The average grain size of both materials is less that $1 \mu \mathrm{m}$. Silicon nitride has a relatively equiaxed microstructure with an aspect ratio (ratio length/thickness) of about 3-4. The grain boundary phase is homogeneously distributed. The main data for $\mathrm{Si}_{3} \mathrm{~N}_{4}$ and cemented carbide are listed below:

\begin{tabular}{|c|c|}
\hline $\mathrm{Si}_{3} \mathbf{N}_{4}$ & \\
\hline Sintering additives & $9 \mathrm{wt}, \% \mathrm{Al}_{2} \mathrm{O}_{3}+\mathrm{Y}_{2} \mathrm{O}_{3}$ \\
\hline $\begin{array}{c}\text { Coefficient of thermal } \\
\text { expansion }\left(300^{\circ} \mathrm{C}\right)\end{array}$ & $\alpha \equiv$ approx, $3.2 \times 10^{6} / \mathrm{K}$ \\
\hline Young's modulus & $E=293 \mathrm{GP}$ \\
\hline Density & $\rho=3.2 \mathrm{~g} \mathrm{~cm}^{-1}$ \\
\hline Cemented earbide & \\
\hline $\begin{array}{c}\text { Coefleient of thermal } \\
\text { expansion }\left(300^{\circ} \mathrm{C}\right)\end{array}$ & $\alpha=$ approx. $5.3 \times 10^{-6} / \mathrm{K}$ \\
\hline Young's modulus & $E=668 \mathrm{GPa}$ \\
\hline Density & $\rho=15.2 \mathrm{~g} \mathrm{~cm}^{-3}$ \\
\hline
\end{tabular}

The bending strength of both materials, measured in four-point bending ( 10 samples, RT), is as follows:

\begin{tabular}{llr}
\hline $\mathrm{CC}$ & $\sigma_{4 \mathrm{~Pa}}$ & $1054 \mathrm{MPa}$ \\
$\mathrm{Si}_{3} \mathrm{~N}_{4}$ & $\sigma_{4 \mathrm{~Pa}}$ & $713 \mathrm{MPa}$ \\
\hline
\end{tabular}

The joints have been brazed with an $\mathrm{AgCu} 26.5 \mathrm{Ti} 3$ filler metal at $900{ }^{\circ} \mathrm{C}$ for $10 \mathrm{~min}$ in a vacuum better that $10^{-5}$ mbar. The main data of the filler metal are listed below:

\section{Composition}

Melting range

$$
\begin{aligned}
& \text { Ag70.5Cu26.3Ti3 } \\
& T_{\text {Sol }}=780^{\circ} \mathrm{C} \\
& T_{\text {Liq }}=805^{\circ} \mathrm{C}
\end{aligned}
$$

Brazing temperature

Tensile strength

Coefficient of thermal expansion

Young's modulus

Density

The third base material in the investigations conducted has always been the cementation steel $16 \mathrm{MnCr} 5(\alpha=$ $9 \times 10^{-6} / \mathrm{K}$ ), which is typically used in the fabrication of cutting tools.

In order to improve the strength of the bi-material $\mathrm{Si}_{3} \mathrm{~N}_{4}$-steel and cemented carbide-steel joints, stress reducing interlayers have been employed. Three different materials have been used:

(1) a sintered W-based alloy (cementation material: Ni-alloy), $\alpha=4.2 \times 10^{-6} / \mathrm{K}$

(2) pressed $\mathrm{Cu}-\mathrm{B}_{4} \mathrm{C}$ composite with 20 vol\% $\mathrm{B}_{4} \mathrm{C}$ content, $\alpha=18 \times 10^{-6} / \mathrm{K}$

(3) copper, $\alpha=17 \times 10^{-6} / \mathrm{K}$.

The brazing experiments were conducted in a cold wall furnace at $900{ }^{\circ} \mathrm{C}$ for $10 \mathrm{~min}$. The furnace was heated to $700{ }^{\circ} \mathrm{C}$ and kept at this temperature for 30 $\mathrm{min}$ in order to guarantee a uniform temperature distribution. Then it was heated up to brazing temperature with a gradient of $5 \mathrm{~K} \mathrm{~min}^{-1}$. After brazing, the furnace was cooled down slowly to $500^{\circ} \mathrm{C}$ before the heating was switched off. The specimens were placed in a fixture at an angle of $70^{\circ}$ and brazed, with the metal being placed on top of the ceramic.

Selected brazed samples were cut, ground and polished to allow microstructural examination of the bond regions.

Mechanical testing was carried out using the fourpoint bending test equipment. The test samples had a geometrical size of $10 \times 10 \times 100 \mathrm{~mm}$ and were tested in a jig with an inner span of $40 \mathrm{~mm}$ and an outer span of $80 \mathrm{~mm}$. The displacement rate was $2 \mathrm{~mm} \mathrm{min-}^{-}$.

\section{Experimental results}

\subsection{Microstructures}

A cross-sectional micrograph of a typical silicon nitride-steel joint, brazed w th AgCuTi3 filler metal is shown in Fig. 5. Quantitative SEM/EDS analyses reveal that titanium migrates to the ceramic surface and reacts with the silicon nitride to form a dense and continuous layer of approximately 2-3 $\mu \mathrm{m}$ thickness (point $A$ in the micrograph). From the Gibbs free energy of formation it can be assumed that Ti-nitrides 


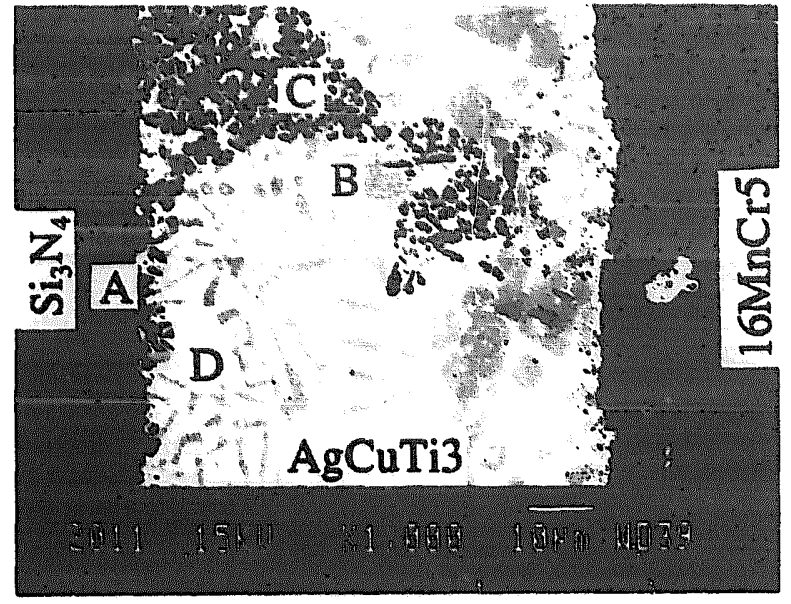

(a)

\section{$\mathrm{Si}_{3} \mathrm{~N}_{4} / \mathrm{CB} 4 / 16 \mathrm{MnCr} 5$ SEM/EDS}

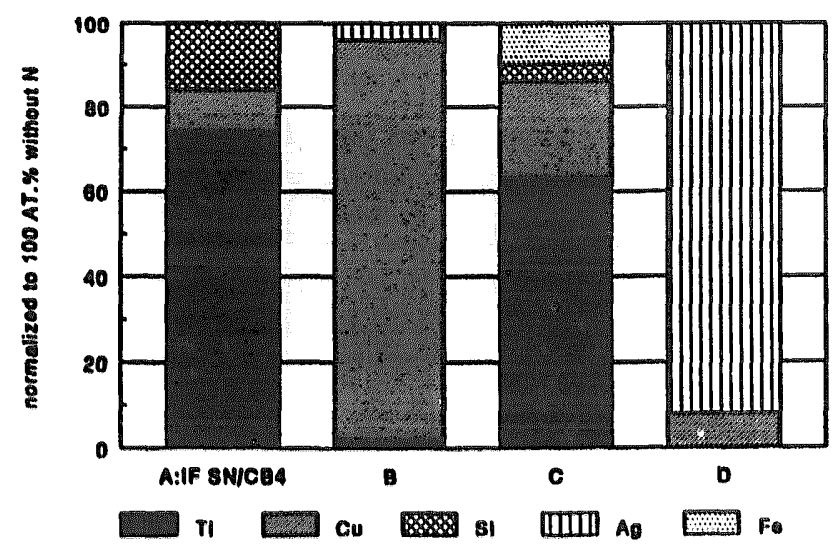

(b)

Fig. 5. (a) Polished section of $\mathrm{Si}_{1} \mathrm{~N}_{4}$ steel joint, brazed with AgCuTi3 filler metal. (b) Quantitative microanalyses of points indicated in micrograph.

and $\mathrm{Ti}$-silicides are the most likely reaction products. Titanium is also enriched in a $<1 \mu \mathrm{m}$ thick discontinuous zone along the steel interface. In the Ag-rich braze gap (point D), Cu-rich primary crystals (point B) prevail over $\mathrm{TiCu}$ intermetallic compounds (point $\mathrm{C}$ ).

The microstructural features of cemented carbide joints brazed with $\mathrm{AgCuTi3}$ (not shown here) are similar to those found for the silicon nitride-steel joints discussed above. However, the reaction layer at the cemented carbide interface appears to $b e$ discontinuous and is less than $1 \mu \mathrm{m}$ thick. WDX measurements show enrichment of $\mathrm{Ti}, \mathrm{Cu}, \mathrm{Fe}$ and $\mathrm{C}$. Intermetallic compounds also contain about 10 at. $\% \mathrm{Fe}$. The cemented carbide itself is porous next to the braze alloy interface. The zone is at lease $25 \mu \mathrm{m}$ thick and contains also up to 7 at.\% copper.

The electron probe micrograph in Fig. 6 shows part of a silicon nitride-steel joint brazed with $\mathrm{AgCuTi3}$ and an additional interlayer, in this case a sintered W-based alloy. The microstructural features resemble those described above. However, at the interlayer interface large CuTiNiW intermetallic compounds of partly complex compositions occur.

Cemented carbide joints with $\mathrm{W}$-based interlayers (not shown here) have discontinuous and less than 0.5 $\mu \mathrm{m}$ thick Ti-rich reaction layer at the cemented carbide interface, and otherwise resemble the silicon nitride bonds with W-based interlayers.

The micrograph in Fig. 7(a) illustrates part of a silicon nitride-steel bond, brazed with $\mathrm{AgCuTi} 3$ filler metal and a composite $\mathrm{Cu} / \mathrm{B}_{4} \mathrm{C}(20$ vol\%) interlayer. The interface between braze alloy and interlayer is diffuse and irregular in shape. The interlayer is deeply penetrated along grain boundaries by the liquid alloy. An enlarged section of the braze gap and the associated $\mathrm{Ti}$ element dot map in Fig. 7(b) and (c) show enrichment of titanium aroung the $\mathrm{B}_{4} \mathrm{C}$ particles and, in a very thin layer, at the ceramic interiace.

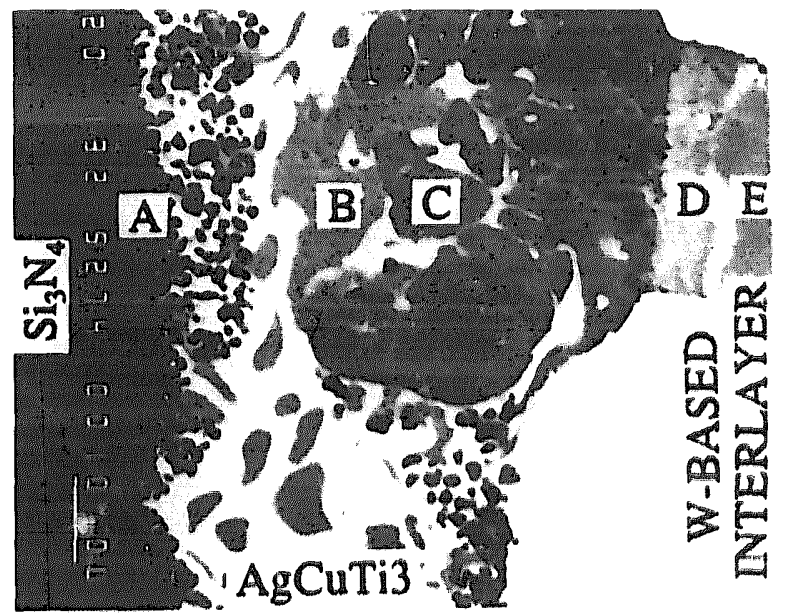

(a)
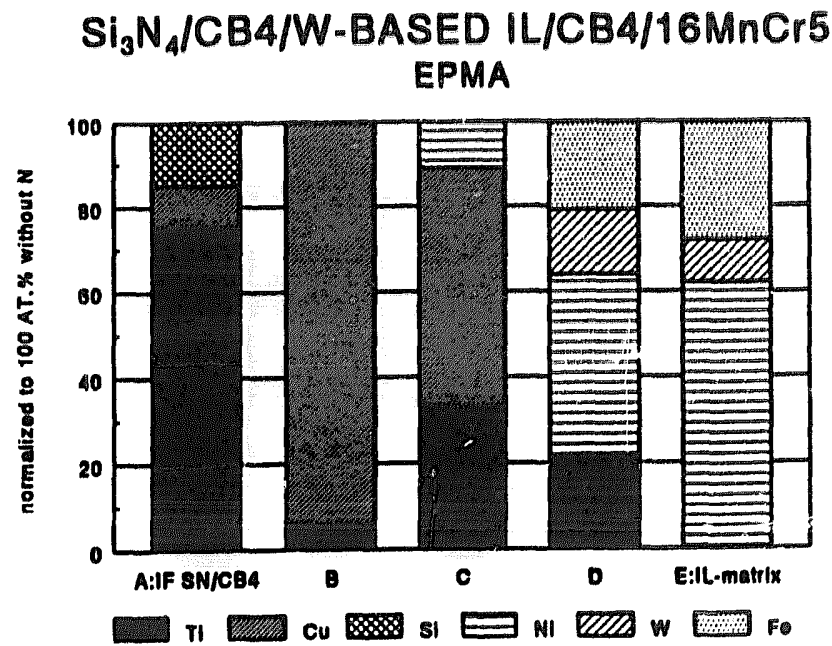

(b)

Fig. 6. (a) Polished section of $\mathrm{Si}_{3} \mathrm{~N}_{4}$-steel joint. brazed with a W-based interlayer and $\mathrm{AgCuTi} 3$ filler metal. (b) Wavelength dispersive microanalyses of points indicated in micrograph. 

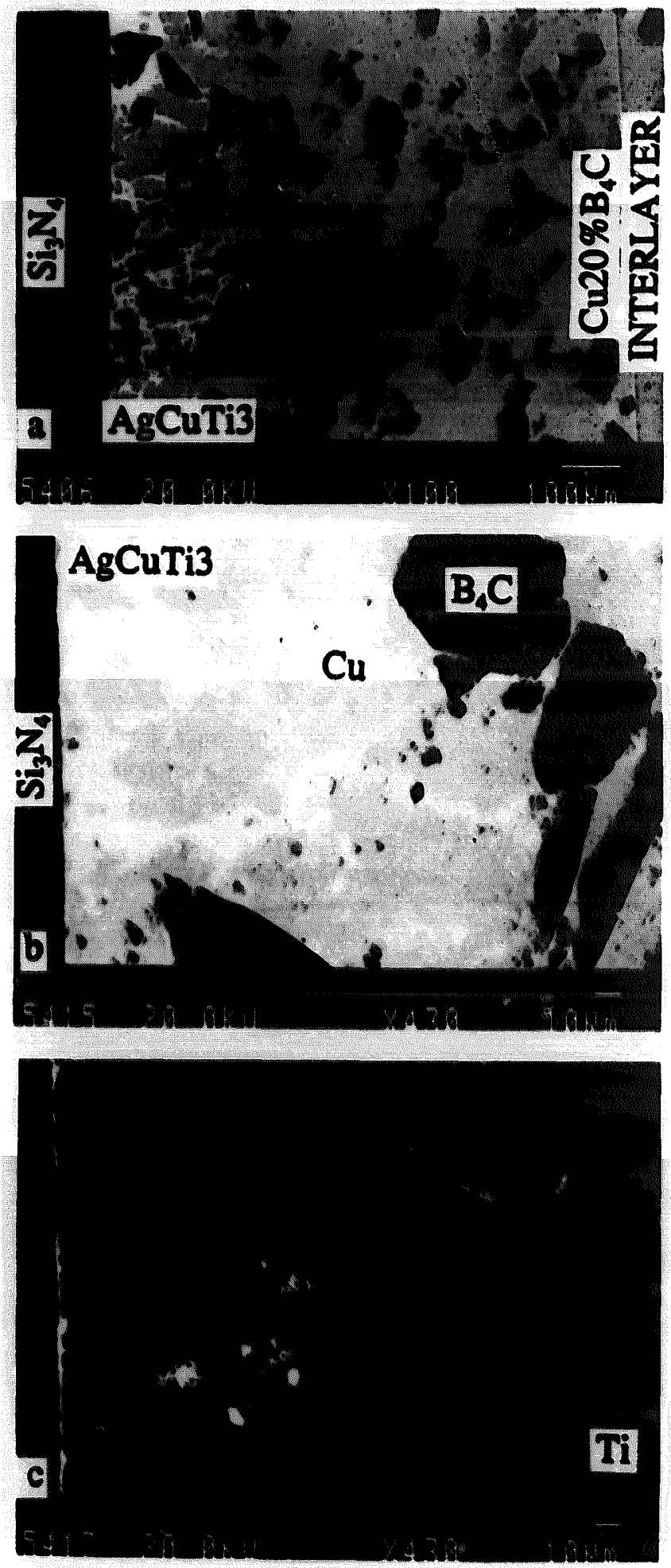

Fig. 7. (a) Polishad section of $\mathrm{Si}_{3} \mathrm{~N}_{4}$-steel joint, brazed with a $\mathrm{Cu} / \mathrm{B}_{4} \mathrm{C}(20$ vol\%) interlayer and $\mathrm{AgCuTi3}$ filler metal; (b) enlarged section of the $\mathrm{Si}_{3} \mathrm{~N}_{4}$-interface area with (c) corresponding $\mathrm{Ti}$ X-ray etement dot map.

\subsection{Sirength}

The main objective was the investigation of the influence of stress reducing interlayers on the joint's strength. Corresponding infinite element analyses have been conducted in order to evaluate different stress-reducing interlayers [12]. A two-dimensional elastic-plastic model has been set up, and nonlinear, thermally dependent material data have been employed. In the experiments described below the influence of ductile and coefficient of thermal expansion (CTE)-adapted materials is assessed.

According to the finite element (FE) calculations, ductile $\mathrm{Cu}$ interlayers of 2,4 , and $6 \mathrm{~mm}$ thickness were used to reduce thermally induced residual stresses in the hard materials especially silicon nitride. Secondly, $\mathrm{Cu}$ / $\mathrm{B}_{4} \mathrm{C}(20 \mathrm{vol} \%)$ composite interlayers were chosen, because they combine the properties of ductile $\mathrm{Cu}$ with a better adaptation of the CTE. As a third variant, $4 \mathrm{~mm}$ thick CTE-adapted sintered W-based interlayers were used, which should reduce stresses, especially in the cemented carbide. Five to eight brazed specimens of each material combination were tested in the four-point bending mode at room temperature and $300{ }^{\circ} \mathrm{C}$.

Ductile interlayers are a problem in four-point bending tests, especially at elevated temperatures, as these tests are designed for the strength determination of rigid materials which show linear (Hookean) stress-strain behavior. The samples showed plastic deformation after an initial linear stress increase and sometimes did not fracture when the maximum load (540 $\mathrm{MPa}$ ) was applied. In these cases the data presented in this paper correspond to the strength values at which ductile deformation started and not the final fracture strength. Some specimens are not fractured at the maximum load of $540 \mathrm{MPa}$. Strength tests with CTEadapted $W$-based interlayers indicate that the majority of bonds exhibit essentially linear behaviour prior to fracture and therefore the data represent the actual fracture strengths.

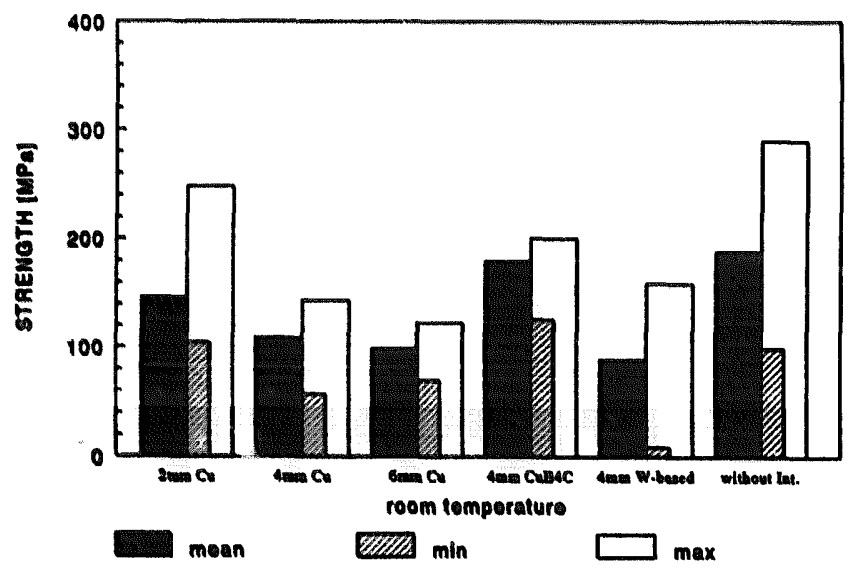

Fig. 8. Four-point bending strength of $\mathrm{Si}_{3} \mathrm{~N}_{4}$-steel joints at room temperature, brazed with $\mathrm{AgCuTi3}$ filler metal and various interlayers. 


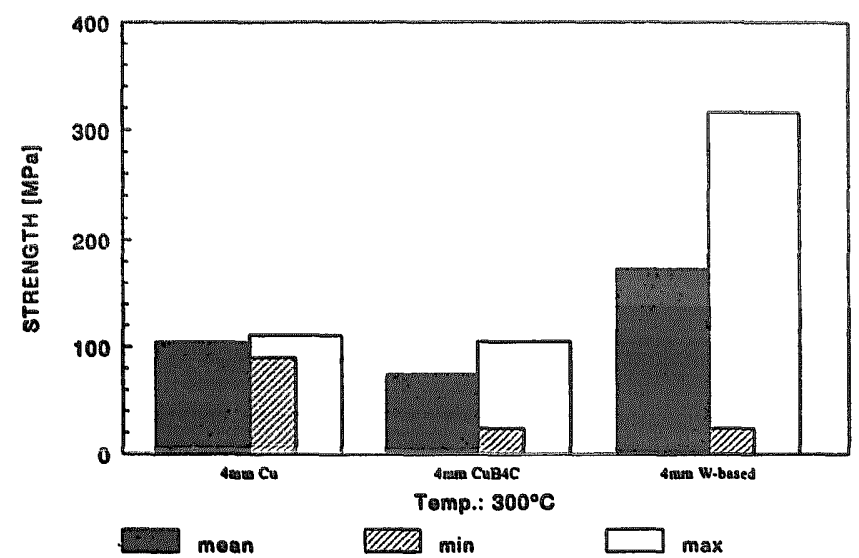

Fig. 9. Four-point bending strength of $\mathrm{Si}_{3} \mathrm{~N}_{4}$-steel joints at $300^{\circ} \mathrm{C}$, brazed with $\mathrm{AgCuTi3}$ filler metal and various interlayers.

The room temperature test results for brazed silicon nitride test samples in Fig. 8 confirm the FE predictions that ductile, $2 \mathrm{~mm}$ thick $\mathrm{Cu}$ interlayers lead to a higher strength, in this case $150 \mathrm{MPa}$ average, than $\mathrm{Cu}$ interlayers of 4 or $6 \mathrm{~mm}$ thickness. The clearly lower average strength values for samples brazed with W-based interlayers also confirm the predictions; the low CTE interlayers are not suitable for stress reduction in the silicon nitride. Remarkable is that two out of six samples failed immediately after loading at $9 \mathrm{MPa}$. Best results (180 MPa average) are achieved with $4 \mathrm{~mm}$ $\mathrm{Cu} / \mathrm{B}_{4} \mathrm{C}(20$ vol\%) composite interlayers. Only these interlayers are suitable to improve the joint strength in the way that the scatter, which occurs in tests with samples without interlayers (see also Fig. 8) is minimized and minimum strength is increased.

In almost all room temperature tests, including the samples without an interlayer, failure occurred within the silicon nitride due to high residual stresses. Exceptions are $50 \%$ of the samples brazed with $\mathrm{Cu} / \mathrm{B}_{4}(20$ vol\%) interlayers. These failed at high strength in the interlayer or in the reaction layer at the ceramic inter-

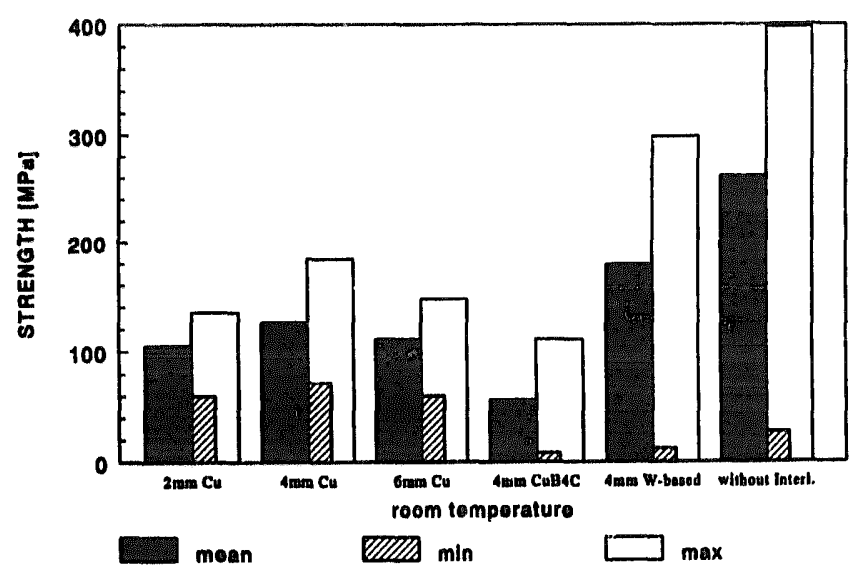

Fig. 10. Four-point bending strength of cemented carbide-steel joints at room temperature, brazed with $\mathrm{AgCuTi} 3$ filler metal and various interlayers.

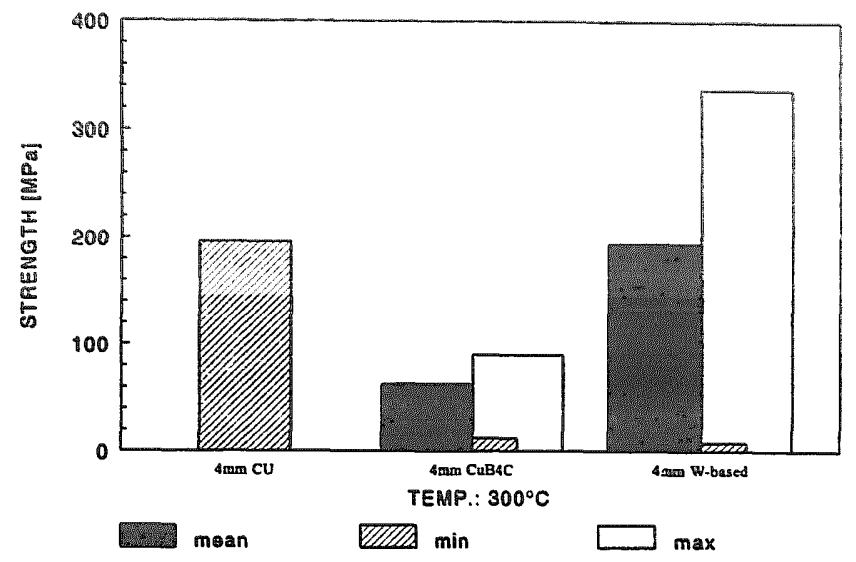

Fig. 11. Four-point bending strength of cemented carbide-steel joints at $300{ }^{\circ} \mathrm{C}$, brazed with $\mathrm{AgCuTi} 3$ filler metal and various interlayers.

face. The latter is most likely due to the metallurgical reactions, which were not taken into account in the theoretical calculations.

Fig. 9 shows a compilation of the results of tests performed with the same sample configurations at 300 ${ }^{\circ} \mathrm{C}$; in this case only $4 \mathrm{~mm}$ thick interlayers are used. The highest average strength, $170 \mathrm{MPa}$, occurs with W-based interlayers, but the scatter is also extremely high. With $\mathrm{Cu}$ interlayers the scatter becomes smaller but the maximum value is lower than at room temperaturc. Tests with $\mathrm{Cu} / \mathrm{B}_{4}(20$ vol\%) interlayers give rise to the lowest strengths of all tests, $75 \mathrm{MPa}$ average.

Low-strength samples with W-based interlayers fail, just as in room temperature tests, within the ceramic, while high-strength specimens debond within the interlayer, close to the braze alloy interfice, as a few at." of $\mathrm{Ti}$ and $\mathrm{Cu}$ can still be found in SEM/EDS analyses performed on the W-interlayer tracture surface. Specimens with ductile interlayers deform physically at stresses above about $100 \mathrm{MPa}$. After the tests the samples are not broken, but show cracks at the ceramic/filler metal interfaces. In one case the bond failed at low stresses within the reaction layer/braze alloy region.

The results show that at an elevated test temperature of $300{ }^{\circ} \mathrm{C}$ residual stresses within the silicon nitride can generally be reduced through interlayers. The fracture strength is then limited by the metallurgical interaction at the interlayer interface in the case of the CTEadapted W-based interlayer. As the interface between the ductile interlayers and the filler metal is very irregular due to the intensive metallurgical interactions, the reaction products at the ceramic interface become the strength-limiting factor. Because of the ductile deformation involved at elevated temperature, the exact fracture strength cannot be determined.

The room temperature test results of brazed cemented carbide samples are shown in Fig. 10. In general ductile $\mathrm{Cu}$ or $\mathrm{Cu} / \mathrm{B}_{4} \mathrm{C}(20$ vol $\%)$ interlayers in 
combination with cemented carbide lead to rather low joint strengths; but within this group the $4 \mathrm{~mm}$ thick
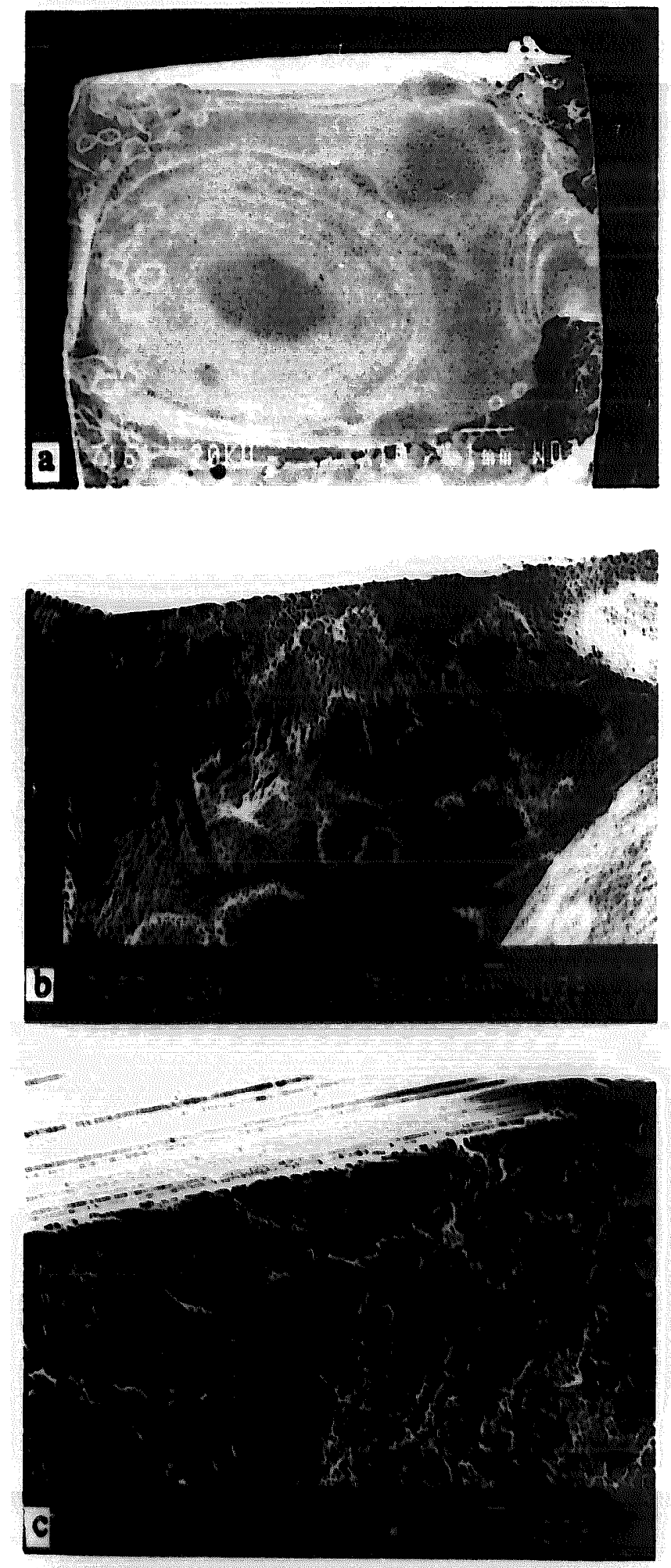

Fig. 12. (a) SEM micrograph of a brazed with $\mathrm{Si}_{3} \mathrm{~N}_{4}$ fracture surface after four-point bending; tensile side at top $(4 \mathrm{~mm} \mathrm{Cu}$ interlayer, room temperature, $140 \mathrm{MPa}$ ), (b) Enlarged section: fracture features like mirror and hackle around fracture origin. (c) Enlarged section of the fracture-initiating flaw, which results from a surface groove.
$\mathrm{Cu}$ interlayers are the most suitable. As predicted by the FE calculations, the use of CTE-adapted W-based interlayers results in considerably higher strength values, i.e. $180 \mathrm{MPa}$. As a negative effect, the scatter is also very large. Compared to test results without interlayers (see also Fig. 10), the strength has not been improved, as those samples obtain an average bending strength of $260 \mathrm{MPa}$.

In samples with $\mathrm{Cu}$ interlayers failure starts predominantly and mostly independent of the strength within the cemented carbide, but crack propagation occurs in some cases partly within the reaction layer between the hard material and the braze alloy. Specimens with $\mathrm{Cu} / \mathrm{B}_{4} \mathrm{C}(20$ vol\%) interlayers show ductile fracture within the interlayer. W-based interlayers fracture at low strength within the cemented carbide. but at higher strength failure also occurs within the interlayer, but very close to the interface.

Specimens with the same sample configurations were also tested at $300{ }^{\circ} \mathrm{C}$. These data are shown in Fig. 11 . Samples with $\mathrm{Cu}$ interlayers did not fracture and show a high degree of plastic deformation in the steel parts after the tests. The deformation starts at approximately $200 \mathrm{MPa}$. Results with $\mathrm{Cu} / \mathrm{B}_{4} \mathrm{C}(20 \mathrm{vol} \%)$ composite interlayers are similar to the data obtained with silicon nitride: the average strength was only $60 \mathrm{MPa}$. The strength values for specimens with $\mathrm{W}$-based interlayers are slightly higher than at room temperature; again showing that residual thermal stresses are reduced at elevated temperatures.

Fracture occurred in the same way as in silicon nitride joints. One sample with a $\mathrm{Cu}$ interlayer failed within the cemented carbide at 195 MPa.

\subsection{Fractography}

All fracture surfaces were examined by SEM/EDS in order to determine the fracture origins. These can be volume or surface defects of the hard materials or residual thermal stresses within the silicon nitide and cemented carbide if the CTE mistiatch between the hard materials and the braze alloy or the reaction products at the interface is too high.

Fracture of silicon nitride due to residual stresses starts in the marginal zone of the ceramic, just above the joint zone. The fracture propagates through the silicon nitride in a direction normal to the largest tensile stresses, creating a dome-shaped fracture surface due to the change in direction of the main tensile stresses within the sample. Transverse surface grooves, often the result of circumferential machining, make failure at these points even more likely. This type of fracture occurs mainly in samples with $\mathrm{Cu}$ interlayers in room temperature tests and samples with W-based interlayers at both temperatures investigated. 

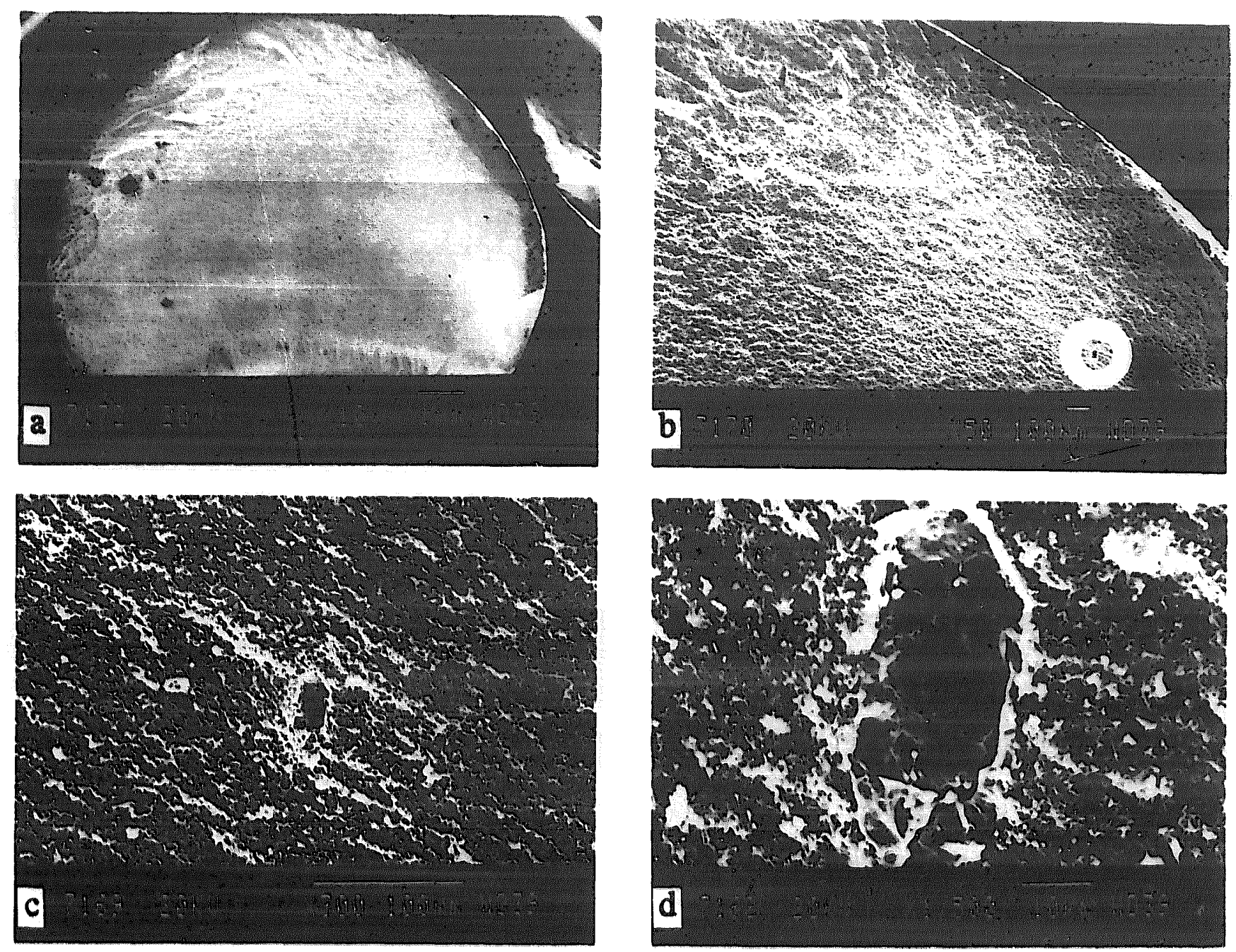

Fig. 13. (a) $\mathrm{SEM}$ mierograph of a $\mathrm{Si}_{3} \mathrm{~N}_{4}$ fracture surface after four-point bending: tensile side at top (no interlayer, room temperature, $330 \mathrm{MPa}$ ). (b), (c), (d) Enlarged sections of the strength limiting flaw, an Fe-rich inclusion within the silicon nitride.

Two low-strength samples failed due to a porous ceramic surface on the tensile side of the test specimen. Otherwise bonded low-strength samples reveal little or no failure characteristics on the fracture surfaces. Fig. 12(a) is a micrograph of a high-strength silicon nitride fracture surface; tensile side on top. The fracture origin, in this case surface grooves on the tensile side of the sample, is illustrated in the enlarged section in Fig. 12(c). Fracture features such as a mirror and hackle around the flaw [13], which help to identify the failure source, are shown in Fig. 12(b). The mirror is a flat and smooth surface which develops around a flaw as the crack propagates radially in a single plane. As soon as the crack begins to deviate from the original plane, radial ridges, called hackles, develop on the fracture surface. These features are very common after fracture of monolithic silicon nitride samples, but are rarely observed in the brazed specimens.

One example of a specimen which failed from a volume defect is shown in Fig. 13(a)-(d). The round sample (10 $\mathrm{mm}$ in diameter) is a $\mathrm{Si}_{3} \mathrm{~N}_{4} /$ steel joint, brazed with $\mathrm{AgCuTi} 3$ filler metal and tested for com= parison with the square joints. The results of the bend. ing tests are not discussed in this paper. The sample failed in a room temperature test at $332 \mathrm{MPa}$ due to an Fe-rich inclusion in the silicon nitride, probably a contamination effect from milling or mixing. The origiii of failure can be found by tracing the radial ridges of the hackle to the strength limiting flaw, which is marked in Fig. 13(b) by a white circle. In two cases volume defects have been glassy inclusions, which led to fracture at low to medium stresses, depending on the flaw size.

Fig. 14(a) and (b) show micrographs of a silicon nitride fracture surface (tensile side on top), where failure occurred primarily along the ceramic/braze alloy interface. SEM/EDS analyses reveal a Ti-rich composition, typical for the reaction layer at the silicon nitride ini-rface. Fracture continues within the ceramic, a sign of hig: residual stresses. 
The overall appearance of the various cemented carbide fracture surfaces, when failure initiated within the cemented carbide, is similar regardless of the interlayers and the test temperatures applied. It cannot be distinguished whether the fracture is due to high residual stresses, the existence of micro-voids, the formation of $\eta$-carbides, or a combination of these.

Fig. 15(a) is a micrograph of part of a typical fracture surface of a high-strength specimen, in this case brazed with a ductile $\mathrm{Cu}$ interlayer. At the tensile side of the fracture surface three debonding levels, i.e. cemented carbide (bottom), reaction layer (top) and metallic braze areas (middle), can be distinguished, suggesting that fracture initiated in or near the cemented carbide/braze alloy interface. The fracture then propagates mainly through the hard material due to high residual stresses, resulting in an irregular fracture surface appearance. The voids in Fig. 15(b), an enlarged section of Fig. 15(a), are presumed to form by
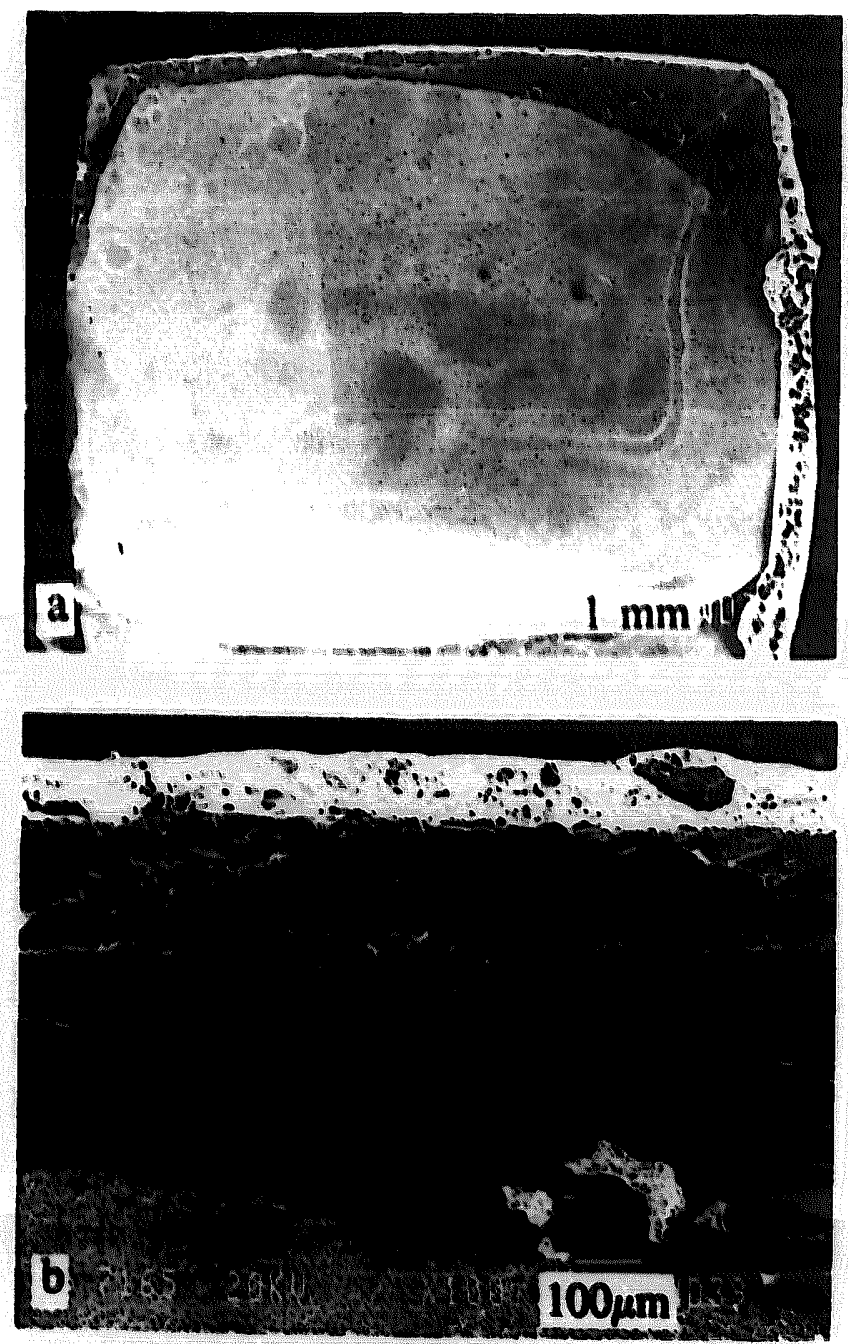

Fig. 14. (a) $\mathrm{Si}_{3} \mathrm{~N}_{4}$ fracture surface, tensile side at top $\left(4 \mathrm{~mm} \mathrm{Cu} / \mathrm{B}_{4}(20\right.$ vol\%) interlayer, room temperature, $185 \mathrm{MPa}$ ). (b) Enlarged section of the upper area, showing the Ti-rich reaction layer with residues of filler metal (white) as strength limiting failure origin.
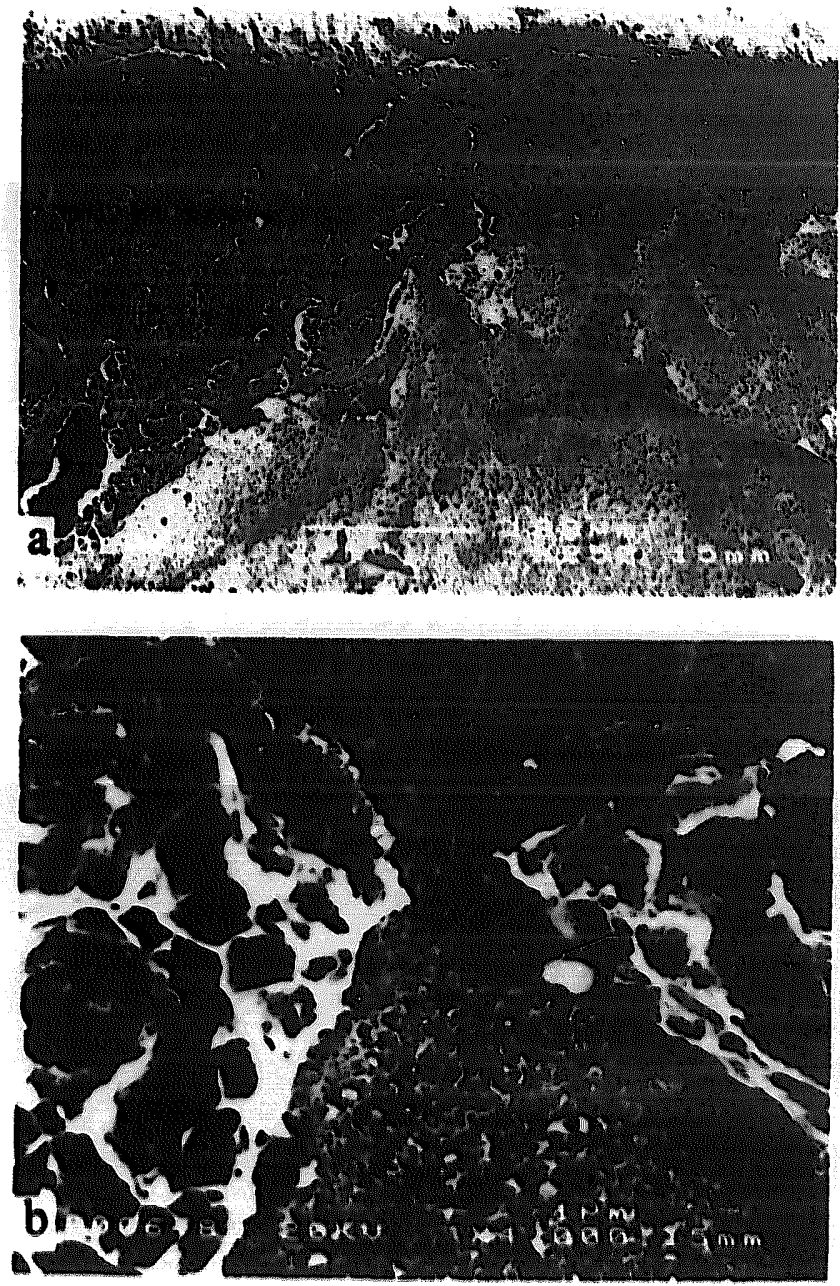

Fig. 15. (a) Section of the tensile side of a cemented carbide fracture surface: failure occurred near the cemented carbide/filler metal interfice (4 $\mathrm{mm} \mathrm{Cu}$ interlayer, room temperature, $185 \mathrm{MPa}$ ). (b) In enlarged section the network of braze alloy on cemented carbide (bottom) and Ti-rich reaction layer (top).

ductile deformation of the filler metal. These fracture features are often observed after tests at elevated temperatures.

The highest strength typically corresponds with failure initiating at the braze alloy/W-based interlayer interface. The strength-limiting flaws in this case are most likely the large brittle intermetallic compounds, which were described in Section 4.1. Low-strength specimens with W-based interlayers fractured within the cemented carbide due to high residual stresses.

Most of the silicon nitride and cemented carbide samples brazed with the $\mathrm{Cu} / \mathrm{B}_{4} \mathrm{C}(20$ vol\%) interlayers fractured, as demonstrated in Fig. 16(a) and (b), in the interlayer itself. Failure occurs both at room temperature and $300{ }^{\circ} \mathrm{C}$ by ductile fracture of the $\mathrm{Cu}$ binder phase around the hard $\mathrm{B}_{4} \mathrm{C}$ particles. The particles leave an impression where they are pulled out of the Cu-matrix. 


\section{Conclusions}

Cemented carbide-steel and silicon nitride-steel joints of high quality can be fabricated by active brazing. Apart from metallurgical aspects a key issue in brazing dissimilar materials is the compensation of thermally induced stresses that are built up because of a mismatch in physical properties. A possible approach to this problem is the use of ductile interlayers that are adapted to the ceramic in thermal expansion behaviour. Contrary to the FE-calculations, the experiments did not show improved bending strength when interlayers were employed. This has to be attributed to metallurgical effects within the joint. Brittle titanium-containing intermetallic phases have been observed, owing to interactions at the interface filler metal-hard materials/interlayer. Fracture due to residual stresses within the hard materials occurs mainly in room temperature tests. At $300^{\circ} \mathrm{C}$, ductile deformation of the interlayers or the steel limits the accuracy of four-point bending tests.
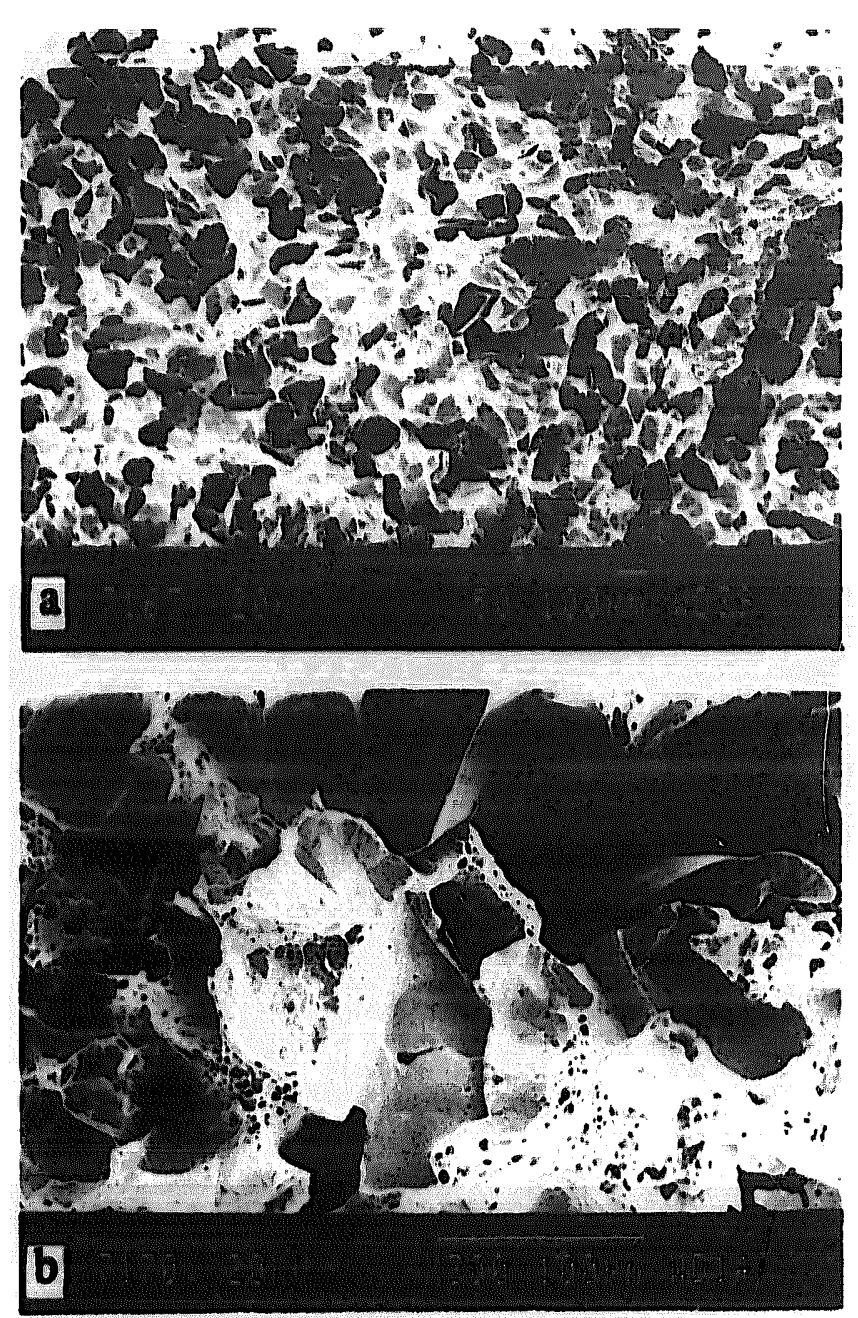

Fig. 16. (a) SEM micrograph of a fracture surface within the $\mathrm{Cu} / \mathrm{B}_{4} \mathrm{C}$ interlayer $\left(4 \mathrm{~mm} \mathrm{Cu} / \mathrm{B}_{4}(20 \mathrm{vol} \%)\right.$ interlayer, room temperature, 200 $\mathrm{MPa}$ ). (b) The enlarged section shows ductile fracture of the $\mathrm{Cu}$ binder around the hard $\mathrm{B}_{4} \mathrm{C}$ particles.
However, the $\mathrm{FE}$ results correspond with the experimental results regarding the geometrical infuence. Provided that metallurgical effects and precipitates can be considered in FE-calculations, a better correspondence between theory and experiment would be feasible. Furthermore it should not be neglected that defects within the ceramic also play a crucial role in the mechanical behaviour of a brazed joint.

\section{Acknowledgements}

The work described is part of an EEC-funded research programme, running under project-No. BE 3295. The authors would like to thank the European Commission for this funding. Furthermore, they would like to thank the project partners Degussa A.G.; Hanau/D, Cerametal S.A.; Luxembourg/L, Hilti A.G.; Schaan/FL and Institut für keramische Komponenten im Maschinenbau -- RWTH Aachen; Aachen/D for their support.

\section{References}

[1] The New Materials Society: Challenges and Opportunities I, Ne'w Materials Markets and Issues (1990). US Department of the Interior, Bureau of Mines, Washington DC.

[2] H.R. Maier, Technische Keramik als Innovationsgrundlage für die Produkt- und Technologie-Entwicklung in NRW. Studie des Ministeriums für Wirtschaft, Mittelstand und Technologie des Landes Nordrhein-Westfalen, 1991.

[3] H. Kolaskat and K. Dreyer, Hartmetalle, Cermets und Keramiken als verschleißbestindige Werkstoffe. Motall 45 (3), (1991) 224.

[4] M.M. Schwark. Coramie Joining. ASM International, Materials Park, OH 44073, 1990.

[5] H..P. Frings. Untersuchungen im System Silber-Kupfer-ZinkSilizium als Grundlage für dic Entwicklung von Loten Fü Hartmetall-Stahl-Verbindungen. Dissertation RWTH Aachen, 1976.

[6] N.N. Technik, Die verbindet. Firmenschrift der Degussa $A G$. Hanau.

[7] M. Stöck. Metallkundliche und mechanische Eigenschaften von Lötverbindungen in Bohrköpfen. Dissertation TU Münehen. 1991.

[8] K.A. Thorsen and H. Fordsmand. Hard metal tool brazing wetting and weak reaction zones, in Proc. 12th Int. Plansec Seminar, 2 (1989) $293-309$.

[9] E. Lugscheider and W. Tillmann. Interfacial reactions between new active filler metals and nonoxide ceramics, in Designing Ceranic Interfaces II, S.D. Peteves (ed.), Commission of the European Communities, Petten. Netherlands (1993) p. 499.

[10] W. Weise, Aktivlöten von Hochleistungskeramik, in Fügen von Hochleistungswerkstoffen, E. Lugscheider and M. Boretius (eds.). VDI-Verlag, Düsseldorf (1993).

[11] W. Tillmann. Aspekte des Aktivlötens nichtoxidischer Ingenieurkeramiken. Dissertation RWTH Aachen, 1992.

[12] H.R. Maier and M. Magin, FEM-Analyse von gelöteten Keramik-Metall-Verbindungen, in Fïgen von Hochleistungsw crkstoffen, E. Lugscheider and M. Boretius (eds.). VDI-Verlag. Düsseldorf, 1993.

[13] D.W. Richerson, Failure analysis, in Modern Ceramic Engineering, Marcel Dekker, New York, 1982. 